\title{
E-LEARNING IN PROFESSIONALLY ORIENTED GERMAN COMMUNICATIVE COMPETENCE FORMATION OF STUDENTS MAJORING IN TOURISM MANAGEMENT
}

\author{
Oksana Bihych \\ Kyiv National Linguistic University, Kyiv, Ukraine \\ bkbpearl@gmail.com \\ Yana Okopna \\ Kyiv National Linguistic University, Kyiv, Ukraine \\ jana.okopna@gmail.com
}

\begin{abstract}
This paper explores the specific features of E-learning as applied to developing professionally oriented German communicative competence in future tourism managers. With this aim the authors analyse modern trends in E-learning as well as teaching potential of existing platforms. Moodle platform has been chosen to develop the author's computer-based course. The research also includes a pilot training to prove the effectiveness of fulfilling innovative academic and professionally oriented methodological tasks. Within the framework of undertaken research the authors systematise existing scientific concepts and describe SLA teaching strategies using Moodle network support. The procedure of defining the strategy steps in SLA using computer-based learning technologies can be the subject of further studies.
\end{abstract}

Keywords: E-Learning; SLA; future tourism managers; German after English; tertiary schools; professionally oriented communicative competence.

\section{Introduction}

Across the entire world the share of services in GDP is continuously growing (The World Bank. World Development Indicators: Structure of output, 2017) and the tourist industry belongs to one of the fastest developing sectors. So, what are the effects of this trend for Ukraine? Our country has a huge potential in this sector, i.e. picturesque and varied landscape, rich history, comparatively easy access by various transport means, hospitality infrastructure. These are just a few arguments in favour of Ukraine's tourism potential. But to realise this potential and ensure its further effective development we need not only "hard assets" like infrastructure, road, hotel capacity, but also "soft skills" like professional and efficient tourism managers. Training of future tourism managers is predominantly provided at tertiary schools, where foreign language training is a minor. Hence, it is of the utmost importance to enhance and improve the language training of future tourism managers in such higher educational schools. And this was the underlining motivation behind this study.

Expansion of international communication, cooperation and exchange of scientific, cultural and professional knowledge has brought about a qualitatively new technology, specifically a communicative professionally oriented approach to teaching foreign languages based on training of students and enhanced communicative, cultural, educational and spiritual needs of the national identity. Computerisation and globalisation of the entire system of teaching foreign languages are declared the most important strategic aspects of the State Education Development Programme of Ukraine for 2012 - 2021 approved by the Decree of the President. The Programme defines the direction to a gradual transition to computer-based and Elearning, which are the linchpin for defining the future challenges of the education system and the highly qualified staff (the State Education Development Programme of Ukraine for 2012 - 2021).

Educational materials using professional texts and international tourism business information form the basis for communicative competence development (Volkova, 2013) in German as a second foreign language after English in future specialists in this field. The communicative competence of future tourism managers includes training means to prepare students for intercultural interaction at an individual level, as well as developing their capacity to search and processes information in both foreign languages (English and German) required for the quality performance of their professional tasks.

Today most scientists share the view that ESL learning forums are an important part of any E-learning system. They provide a multifunctional platform for students and teachers, expanding opportunities for Elearning at home. It also enables teachers to monitor their students' progress at any stage of SLA and at the same time it allows any student to take part in any discussion and instantly get feedback from the teacher (Johnson, 2006; Karagiannidis, Politis, Karasavvidis, 2014; Alahuhta, Nordbäck, Sivunen, \& Surakka, 2014).

The capacity to maintain intercultural interpersonal communication and intercultural interpersonal interaction using modern communication technologies serves many viable professional purposes. The business 
requirement to establish and maintain effective intercultural communication with tourism services users, customers and international colleagues by means of information technologies and the need for continuous training and development of second language skills defines yet another educational challenge - ability to skilfully "navigate professional worlds" (Johnson, 2006). But we live in an era where technology is often deemed to be outdated by the time it is mass-produced and reaches the user (Thong \& Calvin, 2014, p. 51).

In the context of globalised economy and society, higher non-linguistic educational institutions face the task of training professionals in international tourism field who speak two or more foreign languages, and have a high level of professional intercultural communicative competence in speaking and writing. To achieve this, at tertiary schools students who have international tourism as their major should be taught not only to freely read the literature in their field in German as their second foreign Language after English, but also to be proficient in spoken German.

Students' SLA achievements depend on such basic conditions as the number of training hours, number of students in a group, teaching methodology, tutors/lecturers qualifications, textbooks, clear setting of goals and SLA objectives (Azzolini, 2014; Karagiannidis, Politis, Karasavvidis, 2014).

The challenge of teaching professionally oriented oral and written communication in German after English as a second foreign language has inspired many Ukrainian scientists who explored the subject in a number of works (Bihych et al., 2013; Nikolaieva, 2013; Obuhova, 2012; Tarnopol's'kyj, 2006; Byram, 2013). They describe a wide range of E-learning applications in future professionals of SLA (Bihych et al., 2014; Perry, Southwell, 2011; Puren, 2002; Vereshhagina, 2011).

However, the computer-based technology of forming German professionally oriented competence in students majoring in tourism management has not been examined in any special study yet.

While learning a second foreign language, future tourism managers should achieve the level of intercultural linguistic and communicative competences necessary and sufficient for further learning activities. However, to function successfully in a competitive international tourism environment and perform in line with expected professional standards they need a wider toolkit and a more varied range of skills that allow best practice and knowledge sharing, making and maintaining business contacts, and other business activities. All these needs should also be taken into account when designing teaching materials and methodology of German as their second foreign language after English.

Teaching the second foreign language after the first one at tertiary schools has certain specific features. In this case, the focus should be shifted to activities maximising the capacities of future tourism managers for intercultural communication, natural connection between students with similar professional interests, searching for professionally significant scientific information in the field of international tourism.

The aim of this article is to define the characteristics of E-learning for developing professionally oriented German communicative competence in future tourism managers enabling intercultural education in the context of competence-based approach.

\section{Method}

The aim of this paper was achieved with the use of the following scientific methods: the comparison and system analysis of psychological, pedagogical, methodological sources, education process monitoring, pilot training with using author`s blended distance course that highlights the effectiveness of creative academic and professionally methodological tasks, work with the author's course "Deutsch nach Englisch 4" for future managers in tourism in small groups or pairs, describing the experimental phases.

Thus, the relevance of the study is based on the needs to train tourism professionals, capable to communicate in both foreign languages. German Studies at the National University for Food Technologies have been developed with the use of the experimental author's course called "Deutsch nach Englisch 4" (Okopna, 2017) which applies Moodle Learning Platform E-

Learning (http://cde.nuft.edu.ua/course/view.php?id=1554). The above platform is used in teaching German as a second foreign language. This is a new direction to respond to the changes in the Ukrainian labour market that includes work placement experience with leading tourist companies in Germany.

\section{Participants}

Following the author's course "Deutsch nach Englisch 4" for future tourism managers, students have the possibility to practice communicative skills and train their communication strategies in both foreign languages (German and English) in small groups or in pairs. It helps students develop the ability to work as a team (listen, give opinions, reach agreements, etc.) and independently (focusing on time management and problem-solving), and supports future tourism professionals to acquire skills for independent learning, performance self-evaluation, and mastering communicative skills at all levels and in teams. 
The findings of the experiment, carried out at the National University for Food Technologies and comprising 49 students majoring in tourism management, proved that the participants reached the required level of German as their second language proficiency.

The findings of experimental research showed that the students working with the author's course in German "Deutsch nach Englisch 4" has achieved level B2 as it is defined in the Common European Framework of Reference for Languages of the Council of Europe. "Deutsch nach Englisch 4" content is tourism-focused. The course is a blended one, as it combines 60 hours of in-class activities along with 30 hours of working on Moodle platform. The starting level is B1. At the start of the course a placement test was performed by the students. Students who have the knowledge level exceeding that of the course may go directly to the final exam (Bihych et al, 2014, p. 142).

\section{Apparatus and materials}

The author's course "Deutsch nach Englisch 4" comprises exercises sets designed for practising general language functions, and at the same time targeted at tourism specific field. The first set is commonly associated with socialising realised through establishing personal contacts (for example, greeting and responding to the greeting, saying goodbye; making introductions; apologising; offering thanks). The second set of exercises is divided into four subgroups: a) identifying function exercises - identifying oneself and another person; asking for and giving personal information (name, age, job, address, birthplace, nationality, civil status, family, customs, tastes, holidays); asking for and giving information about places (location, characteristics, etc.); time: time of day, timetables, dates, duration of an activity; a current situation; b) expressing function exercises - expressing satisfaction or dissatisfaction; expressing preference; expressing a wish; c) inductive function exercises - asking questions and expressing willingness or a wish to do something; stating that something is possible or impossible to do; suggesting an activity; d) metalinguistic function exercises - asking how a word is pronounced in German; asking how to spell a word (accent, apostrophe, comma, point, hyphen, etc.); asking the meaning of a word or expression.

Grammar exercises in the author's course "Deutsch nach Englisch 4" encompass activities to teach students to be able to recognise and appropriately use grammatical structures. The vocabulary content falls mainly into the following areas: shopping (shops and transactions), food and drink, weather, leisure and sport, everyday activities at home, and describing people and places.

\section{Procedure}

All the students have studied the same modules in "German as Second Foreign Language "during the first experimental phase. In the second experimental phase, this model includes "Introduction to German tourism management" and "Introduction to the Hospitality Language and Advertising". Then students are required to choose one pathway, which they will follow during the second and third experimental phase at the National University for Food Technologies. In the second experimental phase, all students have attended skills-based oral and written language classes. During the first six lessons of each term, they have studied "Introduction to German Tourism Management" or "Introduction to the Hospitality Language and Advertising" for two hours per week, according to their chosen pathway.

The Business Pathway curriculum "Introduction to German Tourism Management" comprised the analysis of advertisements; discourse strategies; job application strategies; concepts, facts and terminology of the German economy; marketing in Germany and intercultural aspects of marketing; and, very importantly, towards the end of the second experimental phase, culture shock. The lecture on culture shock proved to be so interesting to the students going abroad that it was then included as a part of the preparation in both languages practised abroad for all the students - future tourism managers - during the second half of each experimental phase, in both pathways of studying "Introduction to German Touristic Management" or "Introduction to the Hospitality Language and Advertising".

The third experimental phase was generally a simulation of a German-speaking environment or, for those studying two languages; it was a simulation of their other target language speaking environment. Students had a chance to participate in a virtual business simulation as Manager Assistants in foreign tourist companies to design and offer different tours of Ukrainians landmarks and sightseeing tours. In their version of a virtual business game students who followed "Introduction to the Hospitality Language and Advertising" pathway were encouraged to apply for jobs in Germany as Manager Assistants in foreign tourist companies, to design and offer different tours of Ukrainians landmarks and sightseeing trips. Some of the advantages of the simulations were as follows:

- interaction between potential employers and students at an early stage;

- early career awareness which can enhance students' motivation to study; 
- students' appreciation of careers guidance as a part of their academic study.

The third experimental phase, for both pathways, "Introduction to German Touristic Management" and "Introduction to the Hospitality Language and Advertising" curriculum includes two hours of "de-briefing" per week during the entire phase. While the first experimental group focused on business communication from the external perspective, the second experimental group which spent the third phase in a virtual game of working abroad, had a chance to access the business communication from inside, based on their experience and studies during their virtual time abroad. The third experimental group in the second experimental phase worked according to the mixed programme designed on the basis of both pathways, "Introduction to German Touristic Management" and "Introduction to the Hospitality Language and Advertising".

The curriculum included "de-briefing" after the third phase of virtual practice abroad and incorporated as much of the students' experience and learning as possible, and in-depth studies from the second phase.

\section{Results and discussion}

Blended learning at tertiary schools is indispensable for future specialists in tourism management. These computer-based SLA programmes will inevitably be used worldwide facilitating students' interaction. The reasons for investing in and developing the systems are as follows.

The author's blended course "Deutsch nach Englisch 4" helped the students develop communicative competences in oral and written interaction. It enabled them to recognise the sounds that are pronounced and those that are not and to distinguish German phonemes. "Deutsch nach Englisch 4" taught future international tourism managers to understand brief oral messages over the telephone, or in public surroundings and communicate in everyday situations. The students acquired the capacity to understand brief announcements and news items and extract information from a written text aimed at general public (signs, posters, leaflets, notes, etc.); write brief, simple texts in German (postcards, notes, personal texts, etc.) and fill in forms with personal details (Bihych, 2017; Okopna, 2013).

At the end of the course students, who were placed in three experimental groups, have achieved positive results. The participants of the experimental groups: 1) have progressed in grammar, pronunciation, use of vocabulary, register, etc. and fluency (speed of production, ability to express ideas and construct discourse), in both speaking and writing, corresponding to level B2 of the Common European Framework of Reference for Languages (85\% of students); 2) have learnt strategies and skills to understand simple authentic written and spoken texts ( $90 \%$ of students); 3 ) have learnt strategies to continue learning independently outside the classroom (95\% of students); 4) have developed the ability to use the language efficiently in everyday situations and have learnt how to use language learning resources - dictionaries, grammars, text books, practice exercises, etc. (95\% of students).

The assessment (Bihych, 2017; Nikolaieva, 2013; Okopna, 2013) has also been run on the Moodle platform. Future tourism managers should attend at least $80 \%$ of the classes in order to be included in the continuous assessment process. The assessment included the following activities. 1) Writing tasks, comprising from three to five writing exercises, after doing which the students were asked to rewrite their texts to improve the initial versions. 2) Portfolios that contained six to eight tasks, covering four language skills. The tasks were to be done at home or in class. The examples of these tasks included: reading worksheets; transformation exercises; mini-tests; self-assessment sheets; information search; production of documents. The days allocated to midcourse exams can be used to work on portfolio activities, for example, listening and reading mini-tests. 3) Speaking activities, comprising one to two speaking activities conducted over the year. These may be individual or group activities, that may take place in the classroom or can be recorded and sent in. Depending on the level and the number of students in the class, these can be monologues, dialogues, presentations, etc. 4) Mid-course tests - one or more mid-course tests are held on the days allocated for this purpose, including a writing test (one or two tasks) and/or speaking test. These tests have the same format as the final exam.

The experimental test results provide the strong proof of acquired competencies. The experimental learning course enhanced proficiency in reading (75\%), writing (73\%), oral (70\%) and auditory (70\%) skills in German for professional purposes. Survey results confirmed that training "Deutsch nach Englisch 4" provided future tourism managers with valuable insights into commercial, marketing and PR tourism management practices in German-speaking countries and improved their career awareness and understanding of "the world of work" as well as offered a wider scope of skills-based language learning grounded on Contemporary German/Austrian Studies.

Our research demonstrates the ease of studying and teaching "Deutsch nach Englisch 4". Future tourism managers has access to the site and study materials at any time. Moreover, the significant advantage is that this platform is "interruptions free", meaning that irrespective of any interferences like health problems, bad 
weather, and other assignments at work, future tourism managers can comfortably follow their second language course. This is the convincing proof of the practical effectiveness of blended learning. In addition, in case of questions left after the in-class activities, any student could easily get support from the explanations on the page related to the subject. Our students can use the communicative techniques in tourist organisations and companies with professionally oriented activities: internal, external and corporate. Learning outcomes relate to communicative activities of future tourism managers in: 1) identifying the vocabulary used in business communication in two foreign languages; 2) identifying grammatical forms typical of business communication in two foreign languages; 3) developing theoretical and practical knowledge of two foreign languages and topics related to the tourism sector.

Learning outcomes are connected with using by our students the specialised language of the tourism sector in both foreign languages and at the same time with using German and English in specific contexts and real situations.

\section{Conclusions}

The analysis of scientific literature shows that the use of information technologies for developing the communicative competence of future tourism professionals in the process of SLA to solve educational problems, to train specialists with critical and creative thinking, capable to function effectively in the changing professional environment, becomes an integral part of modern Ukrainian education.

The modern Ukrainian educational system demonstrates the tendency to shift the focus from mastering the knowledge to the ability to use information, and seek it by means of information technologies. Therefore, communicative competence formation of future tourism specialists in the process of learning/teaching a foreign language and specialists training should include a system to use technologies in future professional work, especially in the context of current information society. The students put all their knowledge of the language into practice in order to accomplish a set of oral and written tasks, both of general nature and specifically related to tourism. In other words, during the experiment we created the environment, which facilitates the learning process, rather than relies on theoretical instructions of teachers, lecturers, and tutors. Through the entire course we encouraged students to actively use the language in class and practise it outside the classroom on the Moodle platform, to carry out communicative tasks similar to the ones they will face in various situations of real life. To conclude, classroom activities are designed to maximise students' participation and help them take ownership of their learning.

We see the perspectives of our future research in developing SLA strategic steps to teach other foreign languages (Spanish, French, and Italian) as second ones on the basis of English.

\section{References:}

Alahuhta, P., Nordbäck, E., Sivunen, A., \& Surakka, T. (2014). Fostering team creativity in virtual worlds. Journal of Virtual Worlds Research, 7(3), 1-22. Retrieved March, 25, 2018 from https://journals.tdl.org/jvwr/index.php/jvwr/article/view/7062

Azzolini, L, Amelina, S., Hamaniuk, V., \& Zhdanova, N. (2014). Ramkova prohrama z nimetskoi movy profesiinoho spilkuvannia dlia vyshchykh navchalnykh zakladiv Ukrainy [The German-language framework for professional communication for higher education institutions in Ukraine]. Kyiv, Ukraine: Lenvit.

Bihych, O. B., Bondar, L. V., Voloshynova, M. M., Maksymenko, L. O., Ohuj, O. M., Simkova, I. O., \& Okopna, Ya. V. (2013). Teoriia $i$ praktyka formuvannia inshomovnoi profesijno oriientovanoi kompetentnosti $v$ hovorinni u studentiv nelinhvistychnykh spetsial'nostej [Theory and practice of formation of foreign language professionally oriented competence in speaking among students of non-linguistic specialties] (O. B. Bihych, Ed.). Kyiv: Vyd. tsentr KNLU.

Bihych, O. B., Voloshynova, M. M., Hladunov, M. S., \& Okopna, Ya. V. (2014). Suchasnyj student u konteksti osobystisnodiial'nisnoho pidkhodu: za rezul'tatamy naukovo-metodychnykh doslidzhen [Modern student in the context of a personality and behaviour approach: on the results of scientific and methodological research] (O. B. Bihych, Ed.). Kyiv, Ukraine : Vyd. tsentr KNLU.

Bihych, O. (Ed.) (2017). Keisova i podkast tekhnolohii formuvannia mizhkulturnoi kompetentnosti: kolektyvna monohrafiia [Case and podcast technology for the intercultural competence formation: collective monograph]. Kyiv, Ukraine: Vyd. tsentr KNLU

Byram, M. (2013). Intercultural communicative competence in foreign language education: questions of theory, practice and research. The Language Learning Journal, 41, 251-253. https://doi.org/10.1080/09571736.2013.836343

Johnson, K.E. (2006). The sociocultural turn and its challenges for second language teacher education. TESOL Quarterly, 40(1), 235257. https://doi.org/10.2307/40264518

Natsionalna stratehiya rozvytku osvity v Ukraina na period do 2021 roky [the State Education Development Programme of Ukraine until 2021] (2013). Retrieved March, 25, 2018 from http://zakon3.rada.gov.ua/laws/show/344/2013\#n10

Nikolaeva, S. Ju. (Ed.) (2013). Metodyka navchannya inozemnyx mov i kul'tur: teoriya i praktyka [Methods of teaching foreign languages and cultures: Theory and Practice]. Kyiv, Ukraine: Lenvit.

Obuhova, N. (2012). Inojazychnyj mediatekst kak sredstvo formirovanija receptivnoj rechevoj kompetencii studentov-bakalavrov [Foreign language media text as a means of forming receptive speech competence of Bachelor students]. Extended abstract of PhD dissertation, Nizhnij Novgorod, Russia.

Okopna, Ya. (2013). Robocha prohrama normatyvnoi navchal'noi dystsypliny inozemna mova (za profesijnym spriamuvanniam) napriam pidhotovky 6.140103 “Turyzm” [ESP curriculum, 6.140103 “Tourism”]. Kyiv, Ukraine: NUKhT. 
Okopna, Ya. (2017). Osoblyvosti modeliuvannia protsesu formuvannia profesiino oriientovanoi komunikatyvnoi kompetentnosti v pysmi (nimetska mova pislia anhliiskoi) [The peculiarities of formation professionally oriented communicative competence in writing (German after English)]. Visnyk Chernihivskoho natsionalnoho pedahohichnoho universytetu imeni T. H. Shevchenka (Seriia: Pedahohichni nauky), 148, 105-107.

Perry, Laura B. \& Southwell, L. (2011). Developing intercultural understanding and skills: models and approaches. Intercultural Education, 6, 453-466. https://doi.org/10.1080/14675986.2011.644948

Puren, Ch. (2002). Perspectives actionnelles et perspectives culturelles en didactique des langues-cultures: vers une perspective coactionnelle co-culturelle. Les langues modernes, 3, 55-77.

Tarnopol's'kyj, O. (2006). Metodyka navchannya inshomovnoyi movlennyevoyi diyal'nosti u vyshhomu movnomu zakladi osvity [Methods of teaching foreign language communication language in higher education institution]. Kyiv, Ukraine: "INKOS".

Karagiannidis, C., Politis, P., \& Karasavvidis, I. (2014). Research on e-learning and ICT in Education. Berlin, Germany: Springer.

The World Bank (2017). World Development Indicators: Structure of output. Retrieved March, 25, 2018 from https://www.wur.nl/en/Education-Programmes/Bachelor/bsc-programmes/bsctourism.htm?gclid=CjwKCAjwi6TYBRAYEiwAOeH7GVS1-5W71EpbCAWT4mmnn_2w5I7AanrTr_Jw2sdpnCHueDBygqVpRoCOYYQAvD_BwE

Thong, M.S. \& Calvin, M.E. (2014). Technology - boon or bane? Pointer, Journal of the Singapore Armed Forces, 40 (4), $50-61$. Retrieved March, 25, 2018 from https://www.mindef.gov.sg/oms/content/dam/imindef_media_library/graphics/pointer/PD F/2014/Vol.40\%20No.4/6)\%20V40N4_Technology\%20-\%20Boon\%20or\%20Bane\%20.pdf

Vereshhagina, N. (2011). Modernizacija sistemy metodicheskoj podgotovki bakalavra i magistra v oblasti estestvennonauchnogo obrazovanija [Modernization of the system of Bachelor and Master training in the field of natural science education]. Vestnik $M G G U, 1,85-96$.

Volkova, N. P. \& Tarnopolskyi, O. B. (2013). Modeliuvannia profesiinoi diialnosti u vykladanni navchalnykh dystsyplin u vyshakh: monohrafiia [Modelling of professional activity in teaching academic disciplines in higher education institutions: monograph (O. B. Tarnopolskyi, Ed.). Dnipro, Ukraine: Dnipropetr. un-t im. Alfreda Nobelia.

Received: April 30, 2018

Accepted: June 11, 2018 